\title{
Low occurrence of extended-spectrum cephalosporinase producing Enterobacteriaceae and no detection of methicillin-resistant coagulase-positive staphylococci in healthy dogs in Sweden
}

\author{
Stefan Börjesson ${ }^{1,2^{*}}$, Lotta Gunnarsson², Annica Landén ${ }^{2}$ and Ulrika Grönlund ${ }^{3}$
}

\begin{abstract}
Sweden has a long tradition of monitoring occurrence of antibiotic resistant bacteria in both animals and humans, but there currently is no organised and harmonized monitoring on carriage of Enterobacteriaceae producing extended-spectrum beta-lactamase (ESBL), plasmid-mediated AmpC beta-lactamase (pAmpC), or methicillin-resistant coagulase positive staphylococci e.g. methicillin-resistant Staphylococcus aureus (MRSA) and methicillin-resistant Staphylococcus pseudintermedius (MRSP) in dogs. The aim of the current study was therefore to determine the prevalence of ESBL/pAmpC producing Enterobacteriaceae and methicillin-resistant coagulase positive staphylococci in healthy dogs in Sweden, and to phenotypically and genotypically characterize any identified isolates. It was shown that $0.9 \%$ (95\% confident interval $0.3-2.7 \%)$ of the dogs $(n=325)$ carried multi-resistant ESBL-producing Escherichia coli, but that no methicillin-resistant coagulase positive staphylococci could be detected. In conclusion, the occurrence of multi-drug resistant bacteria remains rare among healthy dogs in Sweden. In addition, the ESBL-producing $E$. coli identified showed genetic characteristics related to those reported from humans.
\end{abstract}

Keywords: bla $a_{\mathrm{CTX}-\mathrm{M},}$ bla $a_{\mathrm{CMY}-2}$, Canine, E. coli, Enterobacteriaceae, ESBL, MRSA, MRSP, pAmpC, S. aureus, S. pseudintermedius

\section{Findings}

Multi-resistant bacteria are an increasing threat to both animal and human health. Enterobacteriaceae producing extended-spectrum beta-lactamase (ESBL) or plasmidmediated AmpC beta-lactamase (pAmpC), and methicillin-resistant coagulase positive staphylococci (MRCPS) are of significant concern. Regarding coagulase positive staphylococci, the main concern in human health is the emergence of methicillin-resistant Staphylococcus aureus

*Correspondence: stefan.borjesson@liu.se

1 Department of Biomedical and Clinical Sciences, Linköping University, 58183 Linköping, Sweden

Full list of author information is available at the end of the article
(MRSA), while for companion animals, particularly among dogs, the concern is primarily methicillin-resistant Staphylococcus pseudintermedius (MRSP). Carriage of ESBL/pAmpC producing Enterobacteriaceae (ESBL/ pAmpC-E) in dogs appears to vary between settings and countries. In Copenhagen, Denmark, 1.9\% of dogs' faecal deposits in public gardens were positive for ESBL-producing Escherichia coli (ESBL-EC) and in Paris, France, $18.5 \%$ of dogs carried ESBL-EC, while $81.8 \%$ of dogs carried ESBL-EC in Faisalabad, Pakistan [1-3]. Other nationwide studies reported $\mathrm{ESBL} / \mathrm{pAmpC}-\mathrm{E}$ carriage rates of $9.0 \%$ in United Kingdom and $22.2 \%$ in Turkey, while in the Netherlands, $10.6 \%$ of dogs were reported

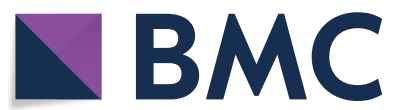

(c) The Author(s) 2020. This article is licensed under a Creative Commons Attribution 4.0 International License, which permits use, sharing, adaptation, distribution and reproduction in any medium or format, as long as you give appropriate credit to the original author(s) and the source, provide a link to the Creative Commons licence, and indicate if changes were made. The images or other third party material in this article are included in the article's Creative Commons licence, unless indicated otherwise in a credit line to the material. If material is not included in the article's Creative Commons licence and your intended use is not permitted by statutory regulation or exceeds the permitted use, you will need to obtain permission directly from the copyright holder. To view a copy of this licence, visit http://creativeco mmons.org/licenses/by/4.0/. The Creative Commons Public Domain Dedication waiver (http://creativecommons.org/publicdomain/ zero/1.0/) applies to the data made available in this article, unless otherwise stated in a credit line to the data. 
to carry ESBL-E [4-6]. Occurrence of MRCPS in dogs generally appears to be lower with reports around $0-3 \%$ positive dogs [7-10].

There are several reasons why it is important to have an up-to-date data on national occurrence of ESBL/pAmpC$E$ and MRCPS in healthy dogs: (i) these dogs are potential high-risk patients in veterinary settings due to the risk of transmission and if becoming diseased, for the risk of failure when treated with antibiotics (ii) sentinel data are essential information when investigating outbreaks in hospitals and clinics to determine if the infectious agent causing the outbreak is acquired in the community or in the hospital and (iii) the zoonotic aspect of carriage with positive dogs functioning as reservoirs or vectors for community-acquired ESBL/pAmpC-E and MRCPS in humans.

In Sweden, there is a relative low usage of antibiotics to dogs and Sweden is generally considered to have a favourable status regarding occurrence of antibiotic resistant bacteria [11]. However, there is no current surveillance on carriage of ESBL/pAmpC-E and MRCPS in dogs or any other companion animals. In addition, the latest screening for ESBL/pAmpC-E and MRCPS in dogs was conducted in 2012 and included only 84 dogs [11]. In that study, only one dog was found to carry pAmpCproducing E. coli (pAmpC-EC) and no MRCPS were detected. The objective of the current study was to provide up-to-date data on prevalence and types of ESBL/ pAmpC-E and MRCPS among healthy dogs in Sweden.

The present study was conducted from May 2017 to May 2018 as a collaboration between The National Veterinary Institute (SVA), Sweden, and AniCura, Sweden. Samples were collected from 325 healthy dogs $>1$ year of age. The samples were taken at a visit at one of eight AniCura animal hospitals in Sweden that participated in the study. Dogs included in the study visited the hospitals for vaccinations or other standard procedures for healthy dogs like $\mathrm{x}$-rays of hips or elbows, blood donations, etc. Two samples were collected per dog using Copan ESwab ${ }^{\mathrm{TM}}$; a rectal swab for ESBL/pAmpC-E isolation and a pooled swab from labial comissure, pharynx, perineum and any wounds (if present) for MRCPS screening. The swabs were sent to one of five participating AniCura laboratories. For ESBL/pAmpC-E, $0.5 \mathrm{~mL}$ of suspension fluid was added to $4.5 \mathrm{~mL}$ buffered-peptone-water and incubated at $36 \pm 1{ }^{\circ} \mathrm{C}$ overnight. After incubation, $10 \mu \mathrm{L}$ of the enrichment broth was plated on MacConkey Agar with $1 \mu \mathrm{g} / \mathrm{mL}$ cefotaxime and incubated at $37^{\circ} \mathrm{C}, 18-22 \mathrm{~h}$. For MRCPS, $0.2 \mathrm{~mL}$ of suspension fluid was added to $4.8 \mathrm{~mL}$ trypticase soy broth with $4 \% \mathrm{NaCl}, 1 \%$ mannitol and $10 \mathrm{mg} / \mathrm{L}$ aztreonam and incubated at $36 \pm 1{ }^{\circ} \mathrm{C}$ overnight. After incubation, $10 \mu \mathrm{L}$ of the enrichment broth was plated on Mannitol salt agar with a $1 \mu$ g oxacillin MASTDISCS ${ }^{\circledR}$ disc (MAST group, Bootle, England) and Brilliance MRSA2-agar (Oxoid AB, Malmö, Sweden) and incubated at $36 \pm 1{ }^{\circ} \mathrm{C}, 18-24 \mathrm{~h}$. One random colony was selected from positive agar plates and sent to SVA for confirmation. At SVA, species identification was performed using Bruker MALDI Biotyper System and suspected ESBL/pAmpC-E isolates were thereafter confirmed phenotypically and tested for antibiotic susceptibility using Sensititre ${ }^{\mathrm{TM}}$ EUVSEC and EUVSEC2 microdilution panels (Thermo Fischer Scientific, Waltham, MA USA) while MRCPS was confirmed by polymerase chain reaction [12]. Verified isolates, including the isolate from the 2012 screening, were subjected to next-generation-sequencing using Illumina based technologies and subjected to alignment and bioinformatic analyses as previously described [13]. Serotypes were determined using SerotypeFinder (https://cge.cbs.dtu. $\mathrm{dk} /$ ).

Three out of 325 dogs were found to carry ESBL-EC (0.9\%; 95\% confident interval $0.3-2.7 \%$ using Wilson Score interval) (Table 1). The prevalence of ESBL-E in Swedish dogs was lower than that reported from other European countries [2-5], but more in-depth comparisons are difficult to make because of general application of different methodologies. However, a Dutch study conducted in 2014-2016 used similar methods as the current study and they found that $10.6 \%$ of the 555 dogs carried ESBL-E [4]. In addition, they also reported that $3.8 \%$ of the owners were carriers, which was slightly lower than the $4.5 \%$ prevalence rate reported from the Dutch general population $[4,14]$. The carriage rate in Dutch citizens is comparable to $4.7 \%$ reported from Sweden in 2013 [15], so it is interesting to note the large difference between carriage rates in Dutch and Swedish dogs. One potential explanation for the difference might be that use of extended spectrum cephalosporins (ESCs) is very limited in Sweden, while in the Netherlands, ESCs, i.e. cefovecin, was frequently used for companion animals [10, 16]. The low usage in Sweden is partly due to a regulation implemented in 2013 which limits the veterinarians' right to prescribe ESCs, stating that these can only be used if alternative choices cannot be expected to be successful (The Swedish Board of Agricultures regulations on drugs and drug usages (In Swedish), SJVFS 2013:42, https://www.jordbruksverket.se). In the current study, all three isolates were also multi-resistant, i.e. resistant to $>2$ antibiotic classes, and carried multiple genes encoding antibiotic resistance (Table 1). Had these strains been the causative agent of an infection, there would have been no or only a limited number of treatment options available for the handling veterinarian due to legalisation and antibiotic treatment policies in Sweden. 
Table 1 Genotypic and phenotypic characteristics in three Escherichia coli isolated from Swedish dogs from May 2017 to May 2018, and from a screening study conducted in 2012

\begin{tabular}{|c|c|c|c|c|c|c|c|c|}
\hline Year & Isolate & $\begin{array}{l}\text { Genes } \\
\text { encoding } \\
\text { ESBL }\end{array}$ & MLST & Serotype & Plasmid replicon types $^{a}$ & $\begin{array}{l}\text { Genes encoding } \\
\text { antibiotic resistance }\end{array}$ & Antibiotic resistance & MIC for $A z^{b}$ \\
\hline 2012 & $\mathrm{CH} 79 \mathrm{ctx}$ & $b l a_{\mathrm{CMY}-2}$ & ST38 & $\mathrm{O} 7 \mathrm{H} 18$ & $\begin{array}{l}\text { colMG828, B/O/K/Z, FIB FII, } \\
\text { p0111 }\end{array}$ & mdfA & $\mathrm{Am}, \mathrm{Cx}, \mathrm{Cm}$ & 4 \\
\hline \multirow[t]{3}{*}{2017} & ACS2 & $b l a_{\mathrm{CTX}-\mathrm{M}-1}$ & ST4496 & $\mathrm{O} 8 \mathrm{H} 28$ & FIA, HI1A, HI1B, Q1 & $\begin{array}{l}\operatorname{aac}(3)-\| \mathrm{b}, \operatorname{aadA} 2, \\
\text { aph(3")--Ib, aph(6)-Ib, } \\
\text { catA1, dfrA12, mdfA, sul1, } \\
\text { sul2, tetA, mphA }\end{array}$ & $\begin{array}{l}\mathrm{Am}, \mathrm{Cx}, \mathrm{Cm}, \mathrm{Chl}, \mathrm{Gm}, \mathrm{Su}, \\
\mathrm{Tm}, \mathrm{Tc}\end{array}$ & 8 \\
\hline & ACS5 & $b l a_{C T X-M-55}$ & ST354 & $\mathrm{O} 1: \mathrm{H} 34$ & col156, FIA, FIB, FII, Q1 & $\begin{array}{l}\text { bla } \text { TEM-1B, } \text { aac(3)-Ild, aadA5, } \\
\text { ant (3")-la, aph(3")-Ib, } \\
\text { aph(6)-Ib, catA1, dfrA17, } \\
\text { mdfA, mphA, sul1, sul2, } \\
\text { tetA, tetD }\end{array}$ & $\begin{array}{l}\text { Am, Cx, Cm, Chl, Ci, Gm, } \\
\text { Nal, Su, Tm, Tc }\end{array}$ & 16 \\
\hline & ACS6 & $b l a_{\mathrm{CTX}-\mathrm{M}-27}$ & ST131 & $\mathrm{O} 25: \mathrm{H} 4$ & col156, col8282, FIA, FIB, FII & $\begin{array}{l}\text { aadA5, ant(3")-la, } \\
\text { aph(3"')-Ib, aph(6)-Id, } \\
\text { dfrA17, mdfA, mphA, } \\
\text { sul1, sul2, tetA }\end{array}$ & $\begin{array}{l}\mathrm{Am}, \mathrm{Cx}, \mathrm{Cm}, \mathrm{Ci}, \mathrm{Nal}, \mathrm{Su}, \\
\mathrm{Tm}, \mathrm{Tc}\end{array}$ & 32 \\
\hline
\end{tabular}

All isolates were tested for susceptibility against ampicillin (Am), azithromycin (Az), cefotaxime (Cx), ceftazidime (Cm), chloramphenicol (Chl), ciprofloxacin (Ci), colistin $(\mathrm{Co})$, gentamicin $(\mathrm{Gm})$, meropenem $(\mathrm{Me})$, nalidixic acid ( $\mathrm{Nal})$, kanamycin $(\mathrm{Km})$, sulfamethoxazole (Su), trimethoprim (Tm), tigecycline (Tg) and tetracycline (Tc). Isolates were defined as resistant if minimum inhibitory concentration (MIC) was above the epidemiological cut-off values (ECOFFs) defined by EUCAST

a Plasmidfinder (https://cge.cbs.dtu.dk/) cannot differentiate between incB, incO, incK, incZ

b No ECOFF defined by EUCAST

In previous European studies, being fed raw meat and/or raw pet food was a risk factor for ESBL/pAmpC$\mathrm{E}$ carriage in dogs $[4,5]$. In addition, the $b l a_{\mathrm{CTX-M-1}}$, carried on incI1 or incK plasmids are frequently identified in the European dog population, which is also common in the European poultry production [2-4, 17]. In the current study, the $b l a_{\mathrm{CTX}-\mathrm{M}-1}$ was identified but the incI1 or incK plasmid could not be detected in this isolate (Table 1). The $b l a_{\mathrm{CTX}-\mathrm{M}-1}$ isolate was also multiresistant, which is inconsistent with the $b l a_{\mathrm{CTX}-\mathrm{M}-1}$ isolates identified in Swedish broilers and the multi-locus sequence type (MLST) ST4496 has not been identified in Swedish poultry $[18,19]$. However, the 2012 screening isolate carried a $b l a_{\mathrm{CMY}-2}$ gene, belonged to ST38 and was positive for incB/O/K/ZB plasmid replicon (Table 1). ST38 E. coli carrying incK $+b l a_{\mathrm{CMY}-2}$ are common on Swedish poultry meat [18], and raw feed containing poultry meat in Sweden has been shown to be contaminated with $E$. coli carrying $b l a_{\mathrm{CMY}-2}$ [20]. In addition to feed, another source for ESBL/pAmpC$\mathrm{E}$ occurrence in dogs could be transmissions from humans. Earlier studies have described that, in addition to $b l a_{\mathrm{CTX}-\mathrm{M}-1}, E$. coli with $b l a_{\mathrm{CTX}-\mathrm{M}-15}$ and $b l a_{\mathrm{CTX}-\mathrm{M}-14}$ are common from dogs and these genes are also the most frequent genes detected in humans $[1-6,14,15$, 21]. It has also been shown that ESBL/pAmpC-E can be shared between owners and dogs [4, 22]. For example, a Swedish study showed that in 22 households with dogowners previously identified with ESBL/pAmpC-EC, identical $b l a_{\mathrm{CMY}-2}$ and $b l a_{\mathrm{CTX}-\mathrm{M}-27}$ positive $E$. coli isolates were confirmed in two households in both humans and dogs [22]. In the current study, the E. coli isolates carried $b l a_{\mathrm{CTX}-\mathrm{M}-55}$ and $b l a_{\mathrm{CTX}-\mathrm{M}-27}$ in addition to the $b l a_{\text {CTX-M-1 }}$ (Table 1). Among humans in Sweden, the genes $b l a_{\mathrm{CTX}-\mathrm{M}-15}, b l a_{\mathrm{CTX}-\mathrm{M}-14}, b l a_{\mathrm{CTX}-\mathrm{M}-27}$ and $b l a_{\mathrm{CTX}-}$ $\mathrm{M}-1$ are the most frequently detected, but the $b l a_{\mathrm{CTX}}$ $\mathrm{M}-55$ is rare [15]. Furthermore, the $b l a_{\mathrm{CTX}-\mathrm{M}-55}$ has been identified from wild-birds and pigs in Sweden, confirming that it occurs in Sweden and within different settings $[10,23,24]$. Additionally, the bla $a_{\text {CTX-M-27 }}$ isolate probably is linked to humans because it was identified as an O25:H4-ST131, which is a pandemic clone, both as non-ESBL and as an ESBL-producer in humans [21]. The bla ${ }_{\mathrm{CTX}-\mathrm{M}-27} \mathrm{O} 25: \mathrm{H} 4-\mathrm{ST} 131$ isolate also was positive for incF-plasmids (Table 1), including incFII which has been strongly linked to the carriage of $b l a_{\mathrm{CTX}-\mathrm{M}-27}$ in human O25:H4-ST131 [15, 21].

None of the 325 dogs in the current study carried MRCPS, but the lack of MRCPS in dogs in Sweden was not unexpected since previous studies have described no or low occurrence in healthy dogs [7-9, 11]. Additionally, both MRSA and MRSP are rare among clinical cases in dogs in Sweden [11]. In fact, only a handful of MRSA cases are reported each year while findings of MRSP are more common with 40-60 cases usually reported annually. In contrast to this study, a recent study from neighbouring Finland on guide dogs described an MRSP occurrence of $3 \%$ [10]. 
The current study demonstrates that occurrence of multi-drug resistant bacteria remains rare among dogs in Sweden, with only $0.9 \%$ of dogs carrying ESBL-producing E. coli and no dogs were identified with methicillinresistant coagulase-positive staphylococci. Based on molecular typing, the results indicated that the occurrence of ESBL-producing E. coli in dogs in Sweden could be due to transmission of strains from humans.

\begin{abstract}
Abbreviations
ECOFF: Epidemiological cut-off value; ESBL: Extended-spectrum beta-lactamase; ESBL/pAmpC-E: ESBL/pAmpC producing Enterobacteriaceae; ESBL-EC: ESBL-producing E. coli; ESC: Extended spectrum cephalosporins; MIC: Minimum inhibitory concentration; MLST: Multilocus sequence typing; MRCPS: Methicillin-resistant coagulase positive Staphylococci; MRSA: Methicillin-resistant S. aureus; MRSP: Methicillin-resistant S. pseudintermedius; pAmpC: Plasmidmediated AmpC beta-lactamase; pAmpC-EC: pAmpC-producing E. coli.
\end{abstract}

\section{Acknowledgements}

The authors would like to thank the personnel involved at the participating laboratories and hospitals for their time and efforts as this study could not have been performed without their valuable help and input. We are also grateful to the dog owners who allowed their dogs to be sampled. The authors are also very grateful to VMD Aleksija Neimane, National Veterinary Institute, Sweden for reviewing the language of the manuscript.

\section{Prior publication}

No prior publication.

\section{Authors' contributions}

SB, LG and UG conceived, designed and executed the study. SB drafted and finalised the manuscript, co-designed and co-wrote the method protocols used in the study by the participating veterinary laboratories, performed NGS and bioinformatic analyses and participated in the laboratory analyses. LG provide intellectual input during the study and commentated on the manuscript draft. AL performed laboratory analysis, wrote and designed the methods protocols, and provided input on the manuscript. UG was responsible for writing the sampling protocols and coordinating the sampling at the veterinary hospitals and helped draft the manuscript. All authors read and approved the final manuscript.

\section{Funding}

Open access funding provided by Linköping University. The study received funding from AniCura Research fund and was co-financed by the National Veterinary Institute (SVA), Uppsala, Sweden.

\section{Availability of data and materials}

The datasets generated and analysed during the current study are available from the corresponding author on reasonable request. Sequence reads for the four isolates have been deposited in the European Nucleotide Archive under the accession number PRJEB35649.

\section{Ethics approval and consent to participate}

Ethical approval was not needed since the study was performed anonymously and the sampling was performed by trained professionals during routine visits at veterinary hospitals. Information and consent for sampling was given by the dog owners when visiting the veterinary hospitals. The study was approved by Animal Welfare Body at SVA on the 2017-03-06, SVA32314.

\section{Consent for publication}

Not applicable.

\section{Competing interests}

The authors declare that they have no competing interests.

\section{Author details}

${ }^{1}$ Department of Biomedical and Clinical Sciences, Linköping University, 58183 Linköping, Sweden. ${ }^{2}$ Department of Animal Health and Antimicrobial Strategies, National Veterinary Institute (SVA), 75189 Uppsala, Sweden. ${ }^{3}$ AniCura, Vendevägen 89, 18232 Danderyd, Sweden.

Received: 7 January 2020 Accepted: 15 April 2020

Published online: 25 April 2020

References

1. Abbas G, Khan I, Mohsin M, Sajjad Ur R, Younas T, Ali S. High rates of CTX-M group-1 extended-spectrum beta-lactamases producing Escherichia coli from pets and their owners in Faisalabad, Pakistan. Infect Drug Resist. 2019;12:571-8.

2. Damborg P, Morsing MK, Petersen T, Bortolaia V, Guardabassi L. CTX-M-1 and CTX-M-15-producing Escherichia coli in dog faeces from public gardens. Acta Vet Scand. 2015;57:83.

3. Haenni M, Saras E, Metayer V, Medaille C, Madec JY. High prevalence of blactX-M-1/Incl1/ST3 and bla $a_{\mathrm{CMY}-2} / \mathrm{Incl1} / \mathrm{ST} 2$ plasmids in healthy urban dogs in France. Antimicrob Agents Chemother. 2014;58:5358-62.

4. van den Bunt G, Fluit AC, Spaninks MP, Timmerman AJ, Geurts Y, Kant $A$, et al. Faecal carriage, risk factors, acquisition and persistence of ESBLproducing Enterobacteriaceae in dogs and cats and co-carriage with humans belonging to the same household. J Antimicrob Chemother. 2019. https://doi.org/10.1093/jac/dkz462.

5. Wedley AL, Dawson S, Maddox TW, Coyne KP, Pinchbeck GL, Clegg P, et al. Carriage of antimicrobial resistant Escherichia coli in dogs: prevalence, associated risk factors and molecular characteristics. Vet Microbiol. 2017:199:23-30.

6. Aslantas O, Yilmaz ES. Prevalence and molecular characterization of extended-spectrum beta-lactamase (ESBL) and plasmidic AmpC betalactamase (pAmpC) producing Escherichia coli in dogs. J Vet Med Sci. 2017;79:1024-30.

7. Vengust M, Anderson ME, Rousseau J, Weese JS. Methicillin-resistant staphylococcal colonization in clinically normal dogs and horses in the community. Lett Appl Microbiol. 2006;43:602-6.

8. Murphy C, Reid-Smith RJ, Prescott JF, Bonnett BN, Poppe C, Boerlin P, et al. Occurrence of antimicrobial resistant bacteria in healthy dogs and cats presented to private veterinary hospitals in southern Ontario: a preliminary study. Can Vet J. 2009;50:1047-53.

9. Mouney MC, Stiles J, Townsend WM, Guptill L, Weese JS. Prevalence of methicillin-resistant Staphylococcus spp. in the conjunctival sac of healthy dogs. Vet Ophthalmol. 2015;18:123-6.

10. Gronthal T, Ollilainen M, Eklund M, Piiparinen H, Gindonis V, Junnila J, et al. Epidemiology of methicillin resistant Staphylococcus pseudintermedius in guide dogs in Finland. Acta Vet Scand. 2015;57:37.

11. Swedres-Svarm 2018. Consumption of antibiotics and occurnce of resistance in Sweden Solna/Uppsala ISSN1650-6332.

12. Stegger M, Andersen PS, Kearns A, Pichon B, Holmes MA, Edwards G, et al. Rapid detection, differentiation and typing of methicillin-resistant Staphylococcus aureus harbouring either mecA or the new mecA homologue mecA(LGA251). Clin Microbiol Infect. 2012;18:395-400.

13. Borjesson S, Greko C, Myrenas M, Landen A, Nilsson O, Pedersen K. A link between the newly described colistin resistance gene mcr-9 and clinical Enterobacteriaceae isolates carrying blaSHV-12 from horses in Sweden. J Glob Antimicrob Resist. https://doi.org/10.1016/j.jgar.2019.08.007. (In press).

14. van den Bunt G, van Pelt W, Hidalgo L, Scharringa J, de Greeff SC, Schurch AC, et al. Prevalence, risk factors and genetic characterisation of extended-spectrum beta-lactamase and carbapenemase-producing Enterobacteriaceae (ESBL-E and CPE): a community-based cross-sectional study, the Netherlands, 2014 to 2016. Euro Surveill. 2019:24(41). https:// doi.org/10.2807/1560-7917.ES.2019.24.41.1800594

15. Ny S, Lofmark S, Borjesson S, Englund S, Ringman M, Bergstrom J, et al. Community carriage of ESBL-producing Escherichia coli is associated with strains of low pathogenicity: a Swedish nationwide study. J Antimicrob Chemother. 2017;72:582-8. 
16. Hopman NEM, van Dijk MAM, Broens EM, Wagenaar JA, Heederik DJJ, van Geijlswijk IM. Quantifying antimicrobial use in Dutch companion animals. Front Vet Sci. 2019;6:158.

17. Dame-Korevaar A, Fischer EAJ, van der Goot J, Stegeman A, Mevius D. Transmission routes of ESBL/pAmpC producing bacteria in the broiler production pyramid, a literature review. Prev Vet Med. 2019;162:136-50.

18. Borjesson S, Egervarn M, Lindblad M, Englund S. Frequent occurrence of extended-spectrum beta-lactamase- and transferable ampc beta-lactamase-producing Escherichia coli on domestic chicken meat in Sweden. Appl Environ Microbiol. 2013;79:2463-6.

19. Borjesson S, Bengtsson B, Jernberg C, Englund S. Spread of extendedspectrum beta-lactamase producing Escherichia coli isolates in Swedish broilers mediated by an incl plasmid carrying bla(CTX-M-1). Acta Vet Scand. 2013;55:3.

20. Nilsson O. Hygiene quality and presence of ESBL-producing Escherichia coli in raw food diets for dogs. Infect Ecol Epidemol. 2015;5:28758.

21. Naseer U, Sundsfjord A. The CTX-M conundrum: dissemination of plasmids and Escherichia coli clones. Micro Drug Resist. 2011;17:83-97.
22. Ljungquist O, Ljungquist D, Myrenas M, Ryden C, Finn M, Bengtsson B. Evidence of household transfer of ESBL-/pAmpC-producing Enterobacteriaceae between humans and dogs_-a pilot study. Infect Ecol Epidemol. 2016;6:31514.

23. Atterby C, Borjesson S, Ny S, Jarhult JD, Byfors S, Bonnedahl J. ESBLproducing Escherichia coli in Swedish gulls - a case of environmental pollution from humans? PLoS ONE. 2017:12(12):e0190380.

24. Söderlund R, Skarin H, Börjesson S, Sannö A, Jernberg T, Aspan A, et al. Prevalence and genomic characteristics of zoonotic gastro-intestinal pathogens and ESBL/pAmpC producing Enterobacteriaceae among Swedish corvid birds. Infect Ecol Epidemol. 2019;9(1):1701399.

\section{Publisher's Note}

Springer Nature remains neutral with regard to jurisdictional claims in published maps and institutional affiliations.
Ready to submit your research? Choose BMC and benefit from:

- fast, convenient online submission

- thorough peer review by experienced researchers in your field

- rapid publication on acceptance

- support for research data, including large and complex data types

- gold Open Access which fosters wider collaboration and increased citations

- maximum visibility for your research: over 100M website views per year

At BMC, research is always in progress.

Learn more biomedcentral.com/submissions 